\title{
Verdier, engasjement og tilhørighet som drivkrefter i lærerstudenters yrkesvalg og utvilkling av laereridentitet
}

\author{
Audhild Løhre ${ }^{1 \star}$, Elin Moen ${ }^{1}$, Randi Etnan ${ }^{1}$, Marit Andersen ${ }^{2}$ \\ and Marit Uthus ${ }^{1}$ \\ ${ }^{1}$ Fakultet for leerer- og tolkeutdanning, NTNU, Trondheim, Norge; ${ }^{2}$ Pedagogisk \\ Psykologisk Tjeneste i Horten kommune, Horten, Norge
}

\section{Sammendrag}

Det fins lite norsk forskning om lærerstudenters motivasjon for å bli lærere. Her presenteres en kvalitativ studie der formålet var å undersøke lærerstudenters motivasjon for å bli lærer, og videre undersøke om utdanningen fremmet deres motivasjon for å utvikle seg som lærere. Studien er forankret i motivasjonsteori om mestringsforventning og verdier. Vi velger i tillegg å benytte teoretiske perspektiver på danning, engasjement og tilhørighet til skolen, siden dette viste seg å være betydningsfulle faktorer for studentenes motivasjon forut for og underveis i studiet. Studiens empiriske grunnlag er 40 studentlogger, alle skrevet midtveis i første studieår. Tekstene er studert gjennom kvalitativ næranalyse. Funnene presenteres i studiens seks kategorier: Til elevens beste, Samfunnsoppdraget, Ankerfeste i forbilder, Tidligere mestringserfaringer, En understøttende praksisperiode og Men, hva med lærestedet? Gjennomgående i studentenes fortellinger framstår verdier, engasjement og tilhørighet som særlige drivkrefter eller kilder til motivasjon. Studentenes erfaringer fra skolepraksisen synes å ha styrket deres identitet som lærer, men det er uvisst hvilken betydning lærestedet har hatt for tilhørighet og identitet.

Nøkkelord: Motivasjon; mestringsforventning; danning; skoletilhørighet

\begin{abstract}
Little research has been done in Norway about what motivates students to choose a career in teaching. This is a qualitative study aimed at examining students' motivation for becoming teachers, as well as examining if the Teacher Education program of study promoted their motivation and development as teachers. The study is anchored in motivation theory about mastery experiences and values. In addition, we choose to make use of theoretical perspectives involving Bildung, engagement and connectedness to school, since these revealed themselves to be important in the students' motivation, both before and during their studies. The empirical basis for this study is 40 student logs, all written halfway through the first year of study. The texts are studied using qualitative analysis. The study's findings are presented in six categories: For the Wellbeing of School Children; Social Commitment; Inspiring Influences; Previous Accomplishments; Fundamental Importance of the Student Practicum period; and But, What About the Teacher Training College?
\end{abstract}

^Korrespondanse: Audhild Løhre, NTNU, Fakultet for lærer- og tolkeutdanning, 7491 Trondheim, E-post: audhild.lohre@ntnu.no 
Values, engagement and the sense of connectedness to school emerge throughout the students' writings as important sources of motivation. The students' experiences from their practicum period seem to have strengthened their identity as teachers. However, it is uncertain as to what influence the Teacher Training College has had on their sense of connectedness and identity.

Keywords: Motivation; mastery experiences; bildung; connectedness to school

Received: September 2015; Accepted: January 2016; Published: April 2016

\section{Introduksjon}

De siste tiårene har det både internasjonalt og i Norge vært en økende interesse for å studere hva som motiverer mennesker for å velge læreryrket som karriere, og hva som skal til for at de forblir i yrket (Roness, 2011; Roness \& Smith, 2010; Skaalvik \& Skaalvik, 2015; Steen-Olsen, 2000; Watt \& Richardson, 2007; Watt et al., 2012). Men fortsatt er det behov for mer kunnskap på området.

Hensikten med denne studien var derfor å undersøke hvorfor studenter i lærerutdanningen ønsket å bli lærere, og hva som kunne være motiverende drivkrefter i studietiden. Førti studentlogger ble analysert med en induktiv, åpen tilnærming. Ut fra studiens empiri kan vi anta at studentenes grunnleggende verdier, deres ønske om å bidra i danning av kommende elever, deres engasjement, tilhørighet til lærerutdanningen samt mestringsforventninger er viktig. Vi har valgt å forstå studentenes motivasjon i lys av teorien om expectancy-value (Wigfield \& Eccles, 1992, 2000), Banduras (1986, 1997) teori om mestringsforventninger og i tillegg støtter vi oss til teori og empiri knyttet til begrepene engasjement, danning og tilhørighet til skolen.

\section{Mestringsforventning og verdier}

Expectancy-value teorien vektlegger både forventning om mestring og betydningen av verdier. Forventningsbegrepet kan ifølge Wigfield \& Eccles (2000) forstås som individers egne forventninger om å lykkes underveis $\mathrm{i}$ aktiviteten, heller enn deres forventninger om et bestemt resultat. Det antas at forventning om mestring kan bli påvirket av blant annet tidligere erfaringer med å mestre lignende oppgaver samt akademisk selvvurdering og attribusjon av tidligere mestringserfaringer. Tro på egen kapasitet og forventning om mestring er dermed vektlagt i motivasjonsteorien.

Teorien legger samtidig sterk vekt på verdidimensjonens betydning for motivasjon. Her løftes det fram fire ulike komponenter der hver enkelt beskriver noe særegent ved verdien av en oppgave eller aktivitet. På norsk kan Wigfield \& Eccles (2000) sine komponenter benevnes som henholdsvis personlig verdi (attainment value or importance), indre verdi (intrinsic value), nytteverdi (utility value, or usefulness), og kostnad (cost) (Skaalvik \& Skaalvik, 2012). Den personlige verdien kjennetegnes ved at aktiviteten/oppgaven oppleves som viktig for den enkelte og er nært forbundet med personens selvoppfatning. Indre verdi omfatter det som oppleves interessant og gir glede når aktiviteten utøves. Nytteverdi innebærer at aktiviteten eller oppgaven anses som vesentlig for å nå framtidige mål, mens kostnad står for ubehagelige eller negative forhold knyttet til aktiviteten/oppgaven (Wigfield \& Eccles, 1992, 2000). 
Verdidimensjonen omtales som kritisk for opprettholdelse av motivasjon over tid, og det forutsettes at aktiviteten eller oppgaven blir oppfattet som verdifull av den enkelte (Wigfield \& Eccles, 1992, 2000). Når det gjelder lærerstudenter og lærere, har internasjonale studier vist at ulike faktorer kan påvirke hvordan de oppfatter verdien av en oppgave. Dette kan blant annet være om oppgaven oppfattes som betydningsfull og viktig eller om den er meningsfull for å nå egne personlige mål (Watt \& Richardson, 2007; Watt et al., 2012).

Banduras $(1997,2006)$ sosialkognitive teori om mestringsforventning har mange likhetstrekk med forventning om mestring i expectancy-value teorien, men det som skiller, er at verdier ikke er fremtredende. Bandura $(1986,1997)$ foreslår fire kilder til forventning om mestring. Den viktigste, autentiske mestringserfaringer, forklares som tidligere erfaringer med å mestre lignende oppgaver. Det å erfare at rollemodeller mestrer, kalles vikarierende erfaringer. Når andre overtaler oss til å tro at vi har den kapasiteten som trengs til å beherske en gitt aktivitet, betegnes det verbal overtalelse. Den fjerde kilden er tidligere fysiologiske eller emosjonelle reaksjoner. Positive reaksjoner vil kunne bidra til å øke forventingen om mestring, mens tidligere negative reaksjoner vil svekke forventningen.

Teori om mestringsforventninger og verdier kan hjelpe oss å forstå lærerstudentenes motivasjon for å bli lærer, og også hva som inspirerte dem underveis i studiet. Det samme gjelder for de teoretiske perspektivene knyttet til begrepene engasjement, danning og tilhørighet, som blir presentert nedenfor.

\section{Engasjement, danning og tilhørighet til skolen}

I vår studie bruker studentene begrepet engasjement $\mathrm{i}$ omtale av ulike temaer. Engasjement er et begrep som er vanskelig å definere tydelig, men det merkes når engasjementet mangler (Newman, 1986). Både i Australia og i OECD-landene er det å skulle identifisere engasjement blitt en anerkjent og viktig problemstilling (Zyngier, 2005). Engasjement er mer enn å trives med eller glede seg til. Det å være engasjert innebærer tilstedeværelse i øyeblikket, som når en person er inspirert, entusiastisk og energisk mens han eller hun utfører arbeidet (Skaalvik \& Skaalvik, 2012). I denne studien forstås engasjement som studentens/lærerens entusiasme ved å skape nysgjerrighet, glede og tilhørighet, både for seg selv og sine elever.

Videre formidler studentene et ønske om å være med å forme, eller danne, elever. Danning er kjernen i begrepet utdanning. I følge John Dewey kan danningen planlegges, men den har ingen fasit (Løvlie, 2013). Danning handler også om at interaksjonen i et fellesskap bidrar til å oppøve kritisk sans (Klafki, 2001) og det foreslås at danning henger sammen med en følelse av forundring (Sundsdal, 2013). Slik vil hvert menneske i løpet av sin oppvekst erfare en stadig veksling mellom egen person og det felleskapet det er en del av. Fra dette kan vi utlede at det også vil være relevant å undersøke om lærerstudentenes intensjoner om bidrag til danning kan utvide vår forståelse av deres motivasjon for læreryrket.

Det å høre til, det å være del av en gruppe eller et større samfunn, anses som et fundamentalt behov for de fleste mennesker (Baumeister \& Leary, 1995). I Maslows (1970) teori om menneskelige behov foreslås tilhørighet som et av de mest 
grunnleggende behovene og noe som må dekkes før individet er motivert for vekst. Definisjoner av tilhørighet til skolen viser til elevenes tro på at de voksne på skolen bryr seg om dem både faglig og som individer (Blum, 2005). Her vektlegges både den akademiske og den emosjonelle dimensjonen, hvor elevens ønske om å gjøre det bra på skolen, så vel som gode relasjoner til lærer og medelever, er av betydning (Wingspread Declaration, 2004). Det er enighet om at elevenes opplevelse av tilhørighet til skolen har stor innvirkning på deres akademiske, sosiale og personlige utvikling (Maddox \& Prinz, 2003; Osterman, 2000). For ungdom og unge voksne synes opplevelse av tilhørighet til lærestedet å ha tilsvarende betydning (Freeman \& Jensen, 2007; Pittman \& Richmond, 2007, 2008). Selv om det er mindre forskning på tilhørighet til lærestedet blant unge voksne studenter, er det vist at egenvurdering av selvverd og akademisk kompetanse blir bedre mens internaliserte problemer avtar når opplevelsen av tilhørighet til universitetet blir sterkere (Pittman \& Richmond, 2008).

Formålet med denne studien var todelt; for det første ville vi undersøke hva som motiverte studentene til å velge lærerutdanningen, og videre ville vi undersøke om utdanningen fremmet deres motivasjon for å utvikle seg som lærere. Vi antar at det teoretiske bakteppet om verdier, mestringsforventning, danning, engasjement og tilhørighet til skolen samlet sett vil være nyttig for å forstå kilder til studentenes motivasjon, både forut for og underveis i lærerutdanningen.

\section{Metode}

Studiens empiriske utgangspunkt er 40 studentlogger, skrevet av 1. årsstudenter etter ett semester i lærerutdanningen. Loggen var en todelt refleksjonsoppgave der studentene først ble bedt om å reflektere over egen motivasjon for valget om å bli lærer, og dernest reflektere over hvorvidt det første semesteret i utdanningen hadde endret deres motivasjon for å bli lærer.

I tillegg til disse 40 loggene, leste vi også logger fra to andre førsteklasser (76 til sammen) som hadde fått tilsvarende oppgave. Disse er ikke utgangspunkt for analyse eller diskusjon i denne studien, men det var interessant for oss å se at det ble gjort mye av de samme refleksjonene også i disse klassene. Når forskningsresultater bekreftes på denne måten, gir det ifølge Tjora (2010) støtte til studiens validitet.

For å få tak i essensen i studentenes motivasjon for å bli lærer, startet vi det kvalitative analysearbeidet med en induktiv, åpen koding av datamaterialet vårt. Gjennom en fram-og-tilbake-prosess med lesing av materialet, fant vi et stort antall koder, og vi så at noen overlappet hverandre. Vi fikk gjennom denne prosessen også bestemt hva som forstyrrer materialet vårt, hva som er «støy» og kunne utelates (Nilssen, 2012).

Neste steg i prosessen var å se sammenhenger mellom kodene, slik at vi kunne begynne å utvikle kategorier. Etter hvert som vi fikk en større forståelse for innholdet i empirien, framsto kategoriene ganske tydelige når det gjelder meningsinnhold. Dette var en krevende, men interessant prosess hvor vi så smått begynte å få en bevissthet rundt innholdet i empirien vår.

Målet med kodingsprosessen var å sitte igjen med noen få, meningsbærende kategorier som skulle gi svar på studiens forskningsspørsmål (Creswell, 2007; 
Nilssen, 2012; Thagaard, 2009). I denne studien fant vi seks kategorier: Til elevens beste, Samfunnsoppdraget, Ankerfeste i forbilder, Tidligere mestringserfaringer, En understøttende praksisperiode og Men, hva med larestedet? som hver ga gode svar eller perspektiver på hvordan verdier, engasjement og tilhørighet kan støtte opp om lærerstudenters motivasjon for valgene de har tatt.

Samtlige studenter ga skriftlig samtykke til at loggene kunne benyttes av oss i denne studien. I tråd med NESH (2006) sine forskningsetiske prinsipp, beskyttes samtlige studenter i denne studien som kilder giennom prinsippene om konfidensialitet og anonymisering.

\section{Presentasjon av funn}

Av de seks kategoriene har fire til hensikt å besvare første del av studiens formål, nemlig hva som motiverte studentene til å bli lærer. De to siste kategoriene søker å belyse om det første semesteret i studiet har fremmet studentenes motivasjon for videreutvikling av egen læreridentitet, som er andre del av studiens formål.

Lærerstudentene syntes å være meget bevisste i sitt yrkesvalg. Det kan virke som en grunnleggende forutsetning for dem å skulle være glad i mennesker, og de har tanker om hva de ønsker å bidra med i forhold til sine kommende elever. Dette ledet fram til kategorien Til elevens beste. Videre så de utdanning av den oppvoksende slekt i et større samfunnsperspektiv, der danning av den enkelte elev sto sentralt. Dette har vi kalt Samfunnsoppdraget. Studentenes fortellinger viser at lærere i deres egen skolegang har vært en sterk motivasjonskraft for valget av utdanning, og dette har vi benevnt Ankerfeste $i$ forbilder. Studentenes egne erfaringer som vikarlærere eller som trenere i fritidsaktiviteter, har også hatt betydning og ble samlet $\mathrm{i}$ kategorien Egne mestringserfaringer.

Det første halvåret i lærerutdanningen består av to hovedkomponenter, der den ene er undervisning ved utdanningsinstitusjonen, som vi heretter vil kalle lærestedet, og den andre er utplassering i skolepraksis. Studentene har vektlagt disse komponentene forskjellig, og det ga en naturlig deling i to kategorier som vi har benevnt En understøttende praksisperiode og Men, hva med lerestedet?

\section{Til elevens beste}

Studentene valgte læreryrket fordi de ønsket å arbeide med mennesker, og da spesielt barn og unge. Så godt som alle de 40 studentene poengterte at de likte å arbeide med barn og unge, og dette ser ut til å være noe studentene tar som en forutsetning for å være lærer.

Jeg har alltid hatt lyst til å arbeide med mennesker. Barn og unge har stått mitt hjerte nærmest ...

Videre viste studentene at de har ambisjoner der de «ønsker at alle skal føle seg sett og hørt». De hadde tenkt gjennom hva de håpet å oppnå for sine kommende elever. I tillegg til det faglige la studentene vekt på å skulle støtte den enkelte eleven, bygge relasjoner og skape et godt klassemiljø. Det kan virke som tanken om å gi personlig støtte gikk hånd $\mathrm{i}$ hånd med ambisjonen om å være faglig engasjerende. 
... det handler også om å skape gode relasjoner og sørge for at elevene skal lære mest mulig på en best mulig måte.

Men det jeg vet er at jeg vil det beste for elever, jeg vil at de skal ha en bra skolegang, at de skal glede seg til å gå på skolen, glede seg til å ha forskjellige fag og glede seg til å lære.

I tråd med sitatet over er det flere som trekker inn begrepene glede og engasjement.

Jeg ønsker å bli den læreren som gir elevene lyst til å utforske og jobbe. Jeg har lyst til å bli den læreren elevene gleder seg til å ha time med. Jeg har lyst til å være med å lage et godt klassemiljø og et godt læringsmiljø. Jeg har lyst til å få ... engasjerte elever, og jeg skal gjøre mitt beste for å oppfylle ønskene mine.

\section{Samfunnsoppdraget}

Enkelte studenter hadde dessuten en sterk bevissthet om muligheten til å være med å forme sine kommende elever som mennesker.

Jeg er opptatt av å sette spor og å være en veileder, ikke bare faglig, men også når det gjelder noe som er like viktig; nemlig å forme elevene til å bli selvstendige og trygge på seg selv og andre.

I tillegg har en lærer et stort ansvar for klassen og er en viktig person i elevenes liv. Jeg ønsker å se at elever mestrer fag og utvikler sin kunnskap.

Oppgaven som lærer ble satt inn i det større samfunnsperspektivet og tillagt stor betydning av de få lærerstudentene som sa noe om dette.

Senere har jeg tenkt mye på hvilken arbeidsoppgave en lærer har og ser på den som en veldig viktig oppgave $i$ dagens samfunn.

Naturfag er, etter min mening, det mest spennende faget i skolen. Ved å vekke elevers nysgjerrighet rundt naturen og hvordan den fungerer, håper jeg å kunne engasjere dem $\mathrm{i}$ andre fag som for eksempel samfunnsfag og politikk.

\section{Ankerfeste i forbilder}

I sine begrunnelser for hvorfor de vil bli lærer, gjenga studentene mange hukommelsesbilder fra egne skoleår. De ga nyanserte framstillinger av lærere de bedømmer i spekteret fra dårlige lærere til superlæreren. Her er det interessant å merke seg at mange av studentene mente at de hadde noe å lære både av de gode og dårlige lærerne.

I løpet av mine år som elev selv har jeg hatt både fantastiske lærere, og ikke fullt så flinke lærere. Nå som jeg selv utdanner meg til å bli lærer ser jeg på erfaringen av å ha flere type lærere som positivt.

Likevel så det ut til å være de såkalt gode lærerne som var den sterkeste inspirasjonskilden til utdanningsvalget. Disse lærerne bidro til positive opplevelser som lærerstudentene ønsket å bringe videre til sine egne kommende elever.

... så har jeg hatt en slik superlærer som rett og slett var helt fantastisk. Hele klassen elsket henne, tross at hun stilte store krav til oss, noe som selvfølgelig var til vårt eget beste. Ikke bare styrket hun klassen faglig, men også sosialt noe som gjorde oss 
til en veldig trygg klasse. Det er slike personer som gjør at jeg vil utdanne meg til lærer, rett og slett for å gi andre barn samme skoleopplevelse som jeg fikk.

Det var ikke bare lærere fra egen skolegang som hadde bidratt til yrkesvalget, men også nærpersoner som selv er lærere. Flere trakk fram at de hadde bekjente som trivdes med å være lærer, og de aller nærmeste, som mamma eller tante, så ut til å ha hatt ekstra stor betydning.

Min mor er lærer. Hun jobber på den samme ungdomsskolen som jeg selv har gått på. Etter å ha hørt hennes fortvilelse over de dårlige resultatene elevene jevnt over leverer på mattetentamener, og ikke minst eksamener, er jeg nysgjerrig. Hvorfor er det slik?

I det siste sitatet ser vi hvordan morens fortellinger hadde pirret studentens nysgjerrighet. Ut fra vår tolking ligger det mye engasjement i det enkle spørsmålet; Hvorfor er det slik? - noe som gir oss grunn til å tro at den kommende studenten vil lete etter svar og løsninger som har til hensikt å gi forbedringer. I tillegg til å ha inspirert og engasjert, ser vi at de dyktige lærerne, forbildene, ga ankerfeste også gjennom å skape skoletilhørighet. Dette ble uttrykt av en student på følgende måte:

Jeg husket jeg gledet meg hver dag til å dra dit og bli tatt godt imot av lærerne som gjorde stoffet vi gjennomgikk lett å forstå og på grunn av alle den morsomme humoren de hadde. ... de behandlet alle rettferdig og gjorde skolen til en lærerik og morsom plass å være.

\section{Tidligere mestringserfaringer}

En stor andel av studentene hadde prøvd seg som lærervikar eller trener i ulike fritidsaktiviteter. Her møtte de utfordringer som ofte krevde mye av dem og der de måtte gjøre en innsats for å lykkes.

Jeg har arbeidet som tilkallingsvikar i en barnehage, og trives godt med barn. Jeg har også vært trener for en gruppe skiskyttere i noen år. Det var noe jeg trivdes godt med, og følte at jeg bidro med noe de dro nytte av.

Det går igjen i studentenes fortellinger at de selv ble motivert når de kunne hjelpe elever til å oppleve mestring. De beskrev positive sirkler der den voksne kom med sitt engasjement og la til rette for elevens læring, så lyktes eleven og ga uttrykk for glede, noe som igjen inspirerte den voksne til å giøre mer. Slike sirkler så ut til å fostre engasjement og gi mestringsglede både hos eleven og den voksne.

...Det jeg også opplevde var at når han ikke forstod måten jeg forklarte noe på, ble jeg veldig engasjert, og ønsket om å hjelpe ble enda sterkere. Det hendte ofte at jeg gikk hjem etter disse timene og grublet på hvordan jeg kunne få ham til å forstå, for eksempel digitalklokka. Det gav meg en utrolig god følelse når han endelig hang med på noe vi hadde strevd med en stund.

Det kom også fram at gode tilbakemeldinger fra andre hadde virket positivt og motivert studentene for læreryrket. De har utsagn som: «Jeg har ofte hørt at jeg har passet bra som lærer ...», «På vurderingsmøtet fikk jeg mange gode tilbakemeldinger både fra skolen og fra foreldrene. Dette ble jeg veldig stolt av ...»og «... de på 
kollokviegruppen min mente jeg forklarte stoffet som de ikke skjønte, på en såpas god måte at de klarte å løse oppgavene selv.»»

\section{En understøttende praksisperiode}

Enkelte av studentene fortalte at de var nervøse i starten av den to uker lange praksisperioden den første høsten i lærerutdanningen: «Jeg var i starten veldig usikker og skalv da jeg underviste ...» og «Det var litt nervepirrende og skummelt ...», men etter hvert opplevde de at det gikk lettere, og erfaringene ga «stor motivasjon til å gjøre det bedre neste gang». Elevene møtte mange typer utfordringer, både faglige, praktiske og organisatoriske. Dette beskrev de som lærerikt og motiverende.

... hverdagen som lærer er full av utfordringer; enten det er en kopimaskin som ikke virker, eller man ikke får vist den filmen man tenkte den timen så må man finne løsninger på det også.

Jeg måtte forklare matematiske ideer på måter jeg ikke hadde tenkt på før, noe jeg virkelig likte. Det var utfordrende, men givende både for meg og elevene.

På lignende vis som studentene hadde opplevd positive sirkler med engasjement, læring og mestringsglede i vikarjobbene før de begynte studiet, fikk de nå tilsvarende opplevelser i praksisperioden. Dette motiverte og gjorde studentene sikrere på at de hadde valgt riktig utdanning.

Det å se denne eleven gå fra å være helt blank i matte til å bli en av de beste i klassen i dette temaet, var veldig motiverende for min egen del også. Det å hjelpe denne eleven med å mestre matten gjorde noe med meg. Jeg fikk på en måte bekreftet at jeg mestrer det å være lærer.

Men når du da får noen kommentarer i slutten av timen at de faktisk har klart noe, og at de ikke syns det er så vanskelig som de trodde, da får du en indre driv om å fortsette med å undervise, når du ser at selv de som sliter mest kan sitte igjen med et smil om munnen fordi akkurat du gjorde noe som hjalp dem. Dette er den største motivasjonen min til å bli lærer.

De to siste sitatene viser også at studentene verdsatte tilbakemeldinger de fikk fra elevene. De kunne få ros og positive bekreftelser fra praksislærer, men i hovedsak virket det som bekreftelser fra elevene var vel så viktige.

En av de mest positive opplevelsene som jeg opplevde i løpet av de to ukene, var nok når en elev virkelig skjønte hva jeg prøvde å forklare. ... Dagen etter kom han med matteboka og viste hvor langt han hadde regnet hjemme dagen før. Han ble utrolig stolt og glad og jeg ser virkelig frem til å se mer av slik læringsglede fremover.

Jeg har blitt mer motivert for å bli lærer og lære mer. En av grunnene til det er den gleden jeg fikk ved å undervise ... I praksis følte jeg ved tilbakemelding fra praksislæreren og elevene at jeg klarte å få frem budskapet/kunnskapen jeg satt på og som jeg ville ha frem.

Studentenes beskrivelser av praksis står i skarp kontrast til deres formidling av opplevelser knyttet til lærestedet og undervisning. Alle de 40 studentene brukte 
erfaringer fra praksisperioden for å begrunne eventuelle endringer i motivasjonen for å bli lærer. Det var derimot bare en femtedel, åtte av 40, som sa noe som helst om lærestedet.

\section{Men, hva med lærestedet?}

De aller fleste studentene, $80 \%$, nevnte ikke lærestedet i det hele tatt. Storparten av studentene tok slik sett ikke undervisning og læring ved lærestedet med i tenkningen om hva som kunne ha påvirket dem det første semesteret.

Ingen studenter sier noe om akademisk støtte eller positive tilbakemeldinger fra faglærere, og det sies heller ingenting om relasjoner til faglærere. Et par elever formidlet at undervisningen, og da spesifikt fysikken, var mer krevende enn de hadde forventet, og to andre uttrykte misnøye med det faglige. For den ene studenten gikk misnøyen på lite opplevd relevans av undervisningen i forhold til det de hadde bruk for i praksis, og den andre studenten savnet tilbakemeldinger på utført arbeid.

Men jeg føler ikke vi lærer det vi burde kunne i enkelte undervisningstimer. For eksempel før jul fikk jeg ikke bruk for noe av det vi lærte om på skolen da jeg selv var ute i praksis. Det giorde at motivasjonen for å følge med på skolen sank, selv om jeg vet hvor viktig det er å være der.

Den eneste individuelle tilbakemeldingen jeg har fått det første halve året er en eksamenskarakter uten kommentarer. Så det jeg føler jeg har lært mest av det forrige semesteret er praksisperioden. Der følte jeg vi fikk god tilbakemelding.

Det siste utsagnet kan tyde på at denne studenten verken opplevde å bli sett eller hørt ved lærestedet. Ettersom det er såpass få som har sagt noe om lærestedet, vet vi ikke om dette er et enkeltstående tilfelle eller om det kan gjelde flere. Av de åtte studentene som formidlet noe om lærestedet, var det fem som uttrykte seg positivt. Her finner vi utsagn som:

Vi har også lært mye spennende på (lærestedet) denne høsten. Mange gode forelesere, med mye kunnskap og en god evne til å lære bort.

... i for eksempel faget matematikk 1 har vi lært helt nye teknikker enn hva jeg lærte da jeg gikk på skolen. Dette ble jeg positivt overrasket over.

Kun en av studentene var tydelig på at han trivdes godt ved lærestedet. Klassen betydde mye for vedkommende, og vi tolker dette som tilknytning til lærestedet.

Siden også motivasjonen min for å bli lærer er høy, er også motivasjonen for å lære høy. Dette fører til at jeg trives veldig godt på lærerhøyskolen, og kommer motivert hver dag. ... Til slutt vil jeg også nevne klassen min ... som en motivasjon. Vi har et veldig godt klassemiljø, noe som fører til at motivasjonen for å lære øker. Dette fører også til at vi jobber godt sammen og lærer av hverandre. Dette tror jeg igjen øker nivået på klassen.

To av de åtte elevene viste til sammenhenger mellom undervisning og praksis. De uttrykte helt klart at de var fornøyde, og at de så fram til å fortsette utdanningen for å bli lærer. 
Alt i alt har jeg lært masse om læreryrket denne høsten, og det gjør at jeg blir mer og mer motivert til å bli en god lærer. Jeg har ikke på langt nær sett, hørt eller følt alle sidene ved yrket, men har fått et positivt innblikk. Jeg gleder meg til å fortsette å lære mer om undervisningsteorier, praksis og fag og føler absolutt at jeg har valgt riktig studieretning!

\section{Videre analyse og diskusjon}

Av de seks kategoriene som omtales i analysen, gir de fire første grunnlag for å besvare studiens første formål ved at studentene her forteller hva som motiverte dem til å velge lærerutdanningen. De to siste kategoriene gir grunnlag for å vurdere studiens andre formål om motivasjon for utvikling av læreridentitet.

Mye av informasjonen i funnene ligger åpent og lett tilgjengelig for leseren; for eksempel beskrivelser av positive opplevelser som vikar i skolen eller hvordan egne lærere har inspirert. Dette vil vi karakterisere som åpenbare motivasjonsfaktorer som er lett å gjenkjenne og forstå. Men i studentenes fortellinger gjenspeiles også andre og mer sammensatte kilder til motivasjon. De som særlig trer fram i vår analyse av materialet, er betydningen av verdier, engasjement og tilhørighet til skolen. Enkeltvis er disse kildene til motivasjon gjenkjennelige i mye av empirien, selv om de er mer tydelige i noen kategorier. Vi har likevel valgt å gjøre noen avgrensinger. Verdier vil i hovedsak bli diskutert ut fra empirien i de to første kategoriene Til elevens beste og Samfunnsoppdraget, siden verdier der framstår som grunnleggende. Diskusjonen av engasjement vil vi i stor grad bygge på empirien i Ankerfeste $i$ forbilder og Tidligere mestringserfaringer ettersom engasjement der er særlig framtredende. I diskusjonen av tilhørighet til skolen vil vi hovedsakelig benytte empiri fra En understottende praksisperiode og Men, hva med larestedet?

Når det gjelder verdikomponentene i expectancy-value-teorien (Wigfield \& Eccles, 1992, 2000), viser analysen at empirien særlig knytter seg til personlig verdi, indre verdi og nytteverdi, noe som bidrar til at vi vektlegger disse tre i den videre drøftingen.

\section{Læreryrket - et verdivalg}

Lærerstudentene synes å være genuint opptatt av den enkelte eleven. I kategorien Til elevens beste bruker de emosjonelle uttrykk som «elsker å jobbe med barn og ungdommer» og disse har «stått mitt hjerte nærmest» når de forklarer motivasjonen for å bli lærer. Utsagnene viser en sterk interesse for oppgavene, noe Wigfield \& Eccles (2000) framhever som betydningsfullt i det som har indre verdi.

I refleksjoner rundt det å se den enkelte, bygge relasjoner og inspirere, forteller studentene samtidig mye om egne ambisjoner; de vil blant annet bli lærere som engasjerer og gir elevene lyst til å utforske og lære. Dette framstår som svært viktig og betydningsfullt for dem, og i dette ligger også et ønske om bekreftelse på egen læreridentitet, noe som ifølge Wigfield \& Eccles (2000) står sentralt innen komponenten personlig verdi.

Studentenes verdigrunnlag kommer kanskje vel så klart til uttrykk i neste kategori, Samfunnsoppdraget. Flere studenter er tydelige på at de ønsker å utrette noe i det store samfunnsperspektivet. I sin framtidige rolle som lærer ønsker de å påvirke, 
forme og hjelpe; kort sagt ønsker de å ha en positiv innvirkning på elevenes liv. De formidler en bevissthet om å ta samfunnsansvar der danning av kommende generasjoner blir vesentlig. Disse fortellingene vitner kanskje mest om det betydningsfulle, det viktige, som i personlig verdi, men har også islett av indre verdi. Men for å kunne bli den personen som «setter spor», er studentene avhengig av en relevant posisjon. De trenger lærerutdanningen for å virke som lærer, og følgelig vil det å utdanne seg som lærer, kunne føre studentene mot målet. I tråd med Wigfield og Eccles (2000) vil dermed det å ta lærerutdanningen også kunne benevnes som nytteverdi.

Vi finner at lærerstudentenes fortellinger knyttet til verdier kan forklares i lys av verdikomponentene i expectancy-value teorien (Wigfield \& Eccles, 1992, 2000). Videre samsvarer våre funn om den verdibaserte motivasjonen for å bli lærer med resultater fra flere land (Watt et al., 2012).

\section{Engasjement som drivkraft}

Det kan virke som mange av studentene er samstemte når de formidler et sterkt engasjement koblet med glede. De vil legge til rette for gode klassemiljø, de vil pirre elevenes nysgjerrighet og støtte opp om lysten til å utforske. De vil at framtidige elever skal glede seg over fagene og det å lære. Her kan engasjementet sees i sammenheng med danning, for når elever blir møtt av lærere som åpner opp for undring, vil danningen også kunne skape en «følelse av forundring» (Sundsdal, 2013).

Studentenes engasjement er tydelig i alle de seks kategoriene. Som vi har sett, formidler studentene giennom de to første kategoriene et håp om å bli engasjerte lærere som kan skape engasjement blant elevene. Likevel kommer engasjementet kanskje klarest fram når studentene gjengir hukommelsesbilder med egne erfaringer, slik det beskrives giennom Ankerfeste i forbilder og Tidligere mestringserfaringer. Den erfaringsbaserte kilden til motivasjon samsvarer med Banduras (1986, 1997) beskrivelser av autentiske mestringsopplevelser og med mestringsforventning i expectancy-value teorien (Wigfield \& Eccles, 1992, 2000).

Mange studenter peker også på betydningen av å ha opplevd egne lærere som engasjerte. Særlig var lærere som la til rette for trygghet og faglig nysgjerrighet, en motivasjonsfaktor i valget av utdanning. Dette kan sees i lys av Banduras (1986, 1997) teori om mestringsforventninger der vikarierende erfaringer antas å virke inn på egne mestringsforventninger. Studentene ga et entydig inntrykk av at de ville føre videre det beste fra sine forbilder, ikke minst det å være engasjert.

Studentenes beskrivelser vitner om energi, entusiasme og et ønske om å inspirere, og dette engasjementet kan fortone seg som en indre motivasjon som ligger forut og som driver dem mot utdanningen og læreryrket. Selv om engasjement ikke er så lett å definere (Newman, 1986; Zyngier, 2005), gir empirien i kategorien En understøttende praksisperiode grunn til å tro at studentenes engasjement også var tilstede $\mathrm{i}$ praksisskolen. Vi kjenner ikke til norske studier om engasjement i skolen, og ser derfor et stort behov for forskning på dette området. 


\section{Tilhørighet i lærerutdanningen}

Studentene forteller mye om grunnlaget for tilhørighet gjennom kategoriene, selv om de ikke direkte nevner begrepet tilhørighet. Empirien viser at lærerstudentene generelt synes å ha opplevd en sterk tilknytning til skolen gjennom sine egne år som elev. Videre har de intensjoner om å skape en skolegang som muliggjør tilhørighet for kommende elever; de vil bygge relasjoner, utfordre, engasjere og gi faglig støtte.

Vi vil nå se nærmere på om lærerstudentene selv opplever tilhørighet til lærerstedet og til praksis. Alle de 40 studentene synes å være begeistret i sine omtaler av praksisoppholdet. Kan erfaringer fra praksis støtte opp om studentenes tilhørighet i lærerutdanningen? Ut fra empirien mener vi det er grunnlag for å anta det. Studentene la mye energi og omtanke i tilrettelegging for den enkelte eleven. Som svar på dette opplevde studentene å bli bekreftet gjennom tilbakemeldinger fra praksislærer og elever. Det kan her synes som bekreftelser fra elever står i en særstilling. Studentene beskriver glede og stolthet når en elev lyktes med en oppgave. Dette bidro til en styrking av studentens motivasjon og identitet som lærer. Det er gjennomgående $\mathrm{i}$ tekstene at direkte og mer indirekte bekreftelser fra elever understøtter den enkelte studentens tro på å kunne bli en god lærer. På det viset fikk studentene mye støtte i den akademiske utøvelsen av oppgavene, noe vi vet er viktig for opplevelse av tilhørighet (Anderman \& Freeman, 2004; McNeely \& Falci, 2004).

Empirien viser at studentene også var bevisste i relasjonsbygging og det å bry seg om den enkelte eleven. Tekstene sier indirekte at studentene likte elevene og at dette var gjensidig. Det betyr at studentene fikk forsterket sine emosjonelle bånd til lærerutdanningen, noe som gjenspeiler den andre viktige bestanddelen $\mathrm{i}$ tilhørighet (Maddox \& Prinz, 2003). Ut fra studentenes refleksjonsnotater kan det virke som elevene er vel så viktige som praksislærer for studentenes tilhørighet til lærerutdanningen. Dette er for oss en ny tanke, som vi heller ikke har funnet omtalt i litteraturen. Følgelig er det behov for mer forskning på dette feltet.

Men, hva så med lærestedet? Det var overraskende at kun en av fem studenter nevnte lærestedet i refleksjonsloggen, og bare én forteller om trivsel, gode relasjoner til medstudenter og samarbeid om oppgaver, opplevelser som gjenspeiler tilhørighet. Videre er det verdt å merke seg at ingen av studentene sier noe om relasjoner til faglærere ved lærestedet, og det er heller ingen som forteller om tilbakemeldinger eller støtte fra faglærer i prosessen med akademisk arbeid. Det betyr at både den emosjonelle og den akademiske komponenten i tilhørighet til skole/lærested (Maddox \& Prinz, 2003; Monahan, Oesterle, \& Hawkins, 2010) så og si ikke omtales. Her er det viktig å understreke at vi ikke kan utlede fra empirien at emosjonell og akademisk støtte fra faglærer er fraværende i første semester av lærerutdanningen. Det empirien forteller, er at studentene i liten grad reflekterer rundt dette. En må dermed være spørrende til hvilken betydning emosjonell og akademisk støtte fra faglærer kan ha hatt for identitetsbygging som lærer hos de 40 studentene i starten av utdanningen. Andre studier har derimot pekt på faglærers betydning for studenters motivasjon, engasjement og opplevelse av tilhørighet til 
universitetet (Freeman et al., 2007). Sammenlignet med grunnskoleelever fins det langt mindre kunnskap om tilhørighet til lærestedet for unge voksne, noe som viser et stort behov for mer forskning.

Så langt har vi omtalt og diskutert verdier, engasjement og tilhørighet hver for seg. Men kanskje er det forbindelser mellom dem som en ikke kjenner tilstrekkelig? Anderman (2003) refererer flere studier som viser sammenhenger mellom skoletilhørighet og engasjement så vel som mellom skoletilhørighet og Eccles verdibaserte motivasjon. Her vil det være behov for longitudinelle studier som både ser på årsaksforhold og eventuelle resiproke forbindelser.

\section{Oppsummering og konklusjon}

Gjennom denne teksten har vi presentert og drøftet refleksjoner fra 40 lærerstudenter med utgangspunkt i deres motivasjon for å bli lærer samt deres motivasjon for utvikling av læreridentitet første studieåret. Noen kilder til motivasjon er åpenbare og lett forståelige, som tidligere mestringserfaringer. Vi har imidlertid lagt større vekt på verdier, engasjement og tilhørighet som kilder til motivasjon. Det verdibaserte grunnlaget for studentenes valg om å bli lærer, synes å være en sterk drivkraft eller kilde til motivasjon. Studentene vil det beste for den enkelte eleven, samtidig som de ser danning i et større samfunnsperspektiv. Videre framstår engasjement som en sterk drivkraft ved at det går en solid linje av engasjement gjennom studentenes fortellinger, fra engasjerte lærere i egen skolegang via formidling av entusiasme i vikarjobber til opplevelse av genuint engasjement i første praksisperiode. Den siste motivasjonskilden er tilhørighet til lærestedet og til praksis. Studentenes fortellinger tilsier at de i praksisskolen fikk erfaringer som samsvarer med tilhørighet, noe som kan ha styrket deres identitet som lærer. I kontrast til dette finner vi lite som tyder på tilhørighet til lærestedet. Funnene gir ingen forklaring på denne forskjellen. Vi ser behov for mer forskning om verdibaserte valg, engasjement og tilhørighet for studenter i lærerutdanningen.

\section{Takk}

Vi retter en stor takk til lærerstudentene som ga oss tilgang til å bruke refleksjonsloggen i forskning. Videre vil vi takke Jean Gaffney Kvendset for oversetting av sammendraget til engelsk.

\section{Forfatterpresentasjoner}

Audhild Løhre, Phd, førsteamanuensis ved Fakultet for lærer- og tolkeutdanning, NTNU. Løhre er tilknyttet Senter for helsefremmende forskning, NTNU, og har et helsefremmende perspektiv i mye av forskningen rundt barn og unge, lærerstudenter, skole og universitet, læring, trivsel og helse. E-post: audhild.lohre@ntnu.no Elin Moen, universitetslektor i pedagogikk ved Fakultet for lærer- og tolkeutdanning, NTNU. Moen sine forskningsinteresser knytter seg først og fremst til barn og unges læring. Herunder fokuseres særlig emner som selvregulert læring/læringsstrategier, motivasjon og selvoppfatning. E-post: elin.moen@ntnu.no

Randi Etnan, universitetslektor i pedagogikk ved Fakultet for lærer- og tolkeutdanning, NTNU. Etnans forskningsinteresser forankres $i$ barn og unges læring, danning, engasjement og helsefremmende utvikling $i$ et 


\section{Audhild Løhre et al.}

salutogent perspektiv. Etnan er særlig opptatt av livskvalitet og trivsel i tilknytning elevers læringsforutsetninger. E-post: randi.etnan@ntnu.no

Marit Andersen, spesialpedagog med master fra Institutt for helsefremmende arbeid, HSN. Andersen jobber som pedagogisk psykologisk rådgiver ved PP-tjenesten i Horten og samarbeider med forskere ved Fakultet for lærer- og tolkeutdanningen, NTNU. Andersen har særlig interesse for helsefremmende læringsmiljø, med vekt på elevers medvirkning og opplevelse av tilhørighet til skolen. E-post: marit.andersen@horten.kommune.no Marit Uthus, Phd, jobber som førsteamanuensis vedFakultet for lærer- og tolkeutdanning, NTNU. Uthus sine forskningsinteresser er knyttet til elever og ansatte i skolen, samt lærerstudenter i lærerutdanningen. Særlig fokuseres emner som læringsmiljø, selvoppfatning, motivasjon og skoletrivsel. Spesialpedagogiske emner opptar henne også. E-post: marit.uthus@ntnu.no

\section{Referanser}

Anderman, L. H. (2003). Academic and Social Perceptions as Predictors of Change in Middle School Students' Sense of School Belonging. The Fournal of Experimental Education, 72(1), 5-22.

Anderman, L. H. \& Freeman, T. M. (2004). Students' sense of belonging in school. I P. R. Pintrich \& M. I. Maehr (Red.), Advances in motivation and achievement. Motivating students, improving schools: The legacy of Carol Midgley vol. 13, (s. 27-63). Amsterdam: Elsevier.

Bandura, A. (1986). Social foundations of thought and action: a social cognitive theory. Englewood Cliffs, N.J: Prentice-Hall.

Bandura, A. (1997). Self-efficacy: the exercise of control. New York: Freeman.

Bandura, A. (2006). Adolescent development from an agentic perspective. I I. F. Pajares \& T. Urdan (Red.), Self-efficacy beliefs of asolescents (s. 1-43). Greenwich, Connecticut: Information Age Publishing.

Baumeister, R. F. \& Leary, M. R. (1995). The Need to Belong: Desire for Interpersonal Attachments as a Fundamental Human Motivation. Psychological Bulletin, 117(3), 497-529.

Blum, R. W. (2005). A case for school connectedness. Educational Leadership, 62(7), 16-20.

Creswell, J. W. (2007). Qualitative inquiry \& research design: choosing among five approaches (2. utg.). Thousand Oaks, Calif: Sage.

Freeman, T. M., Anderman, L. H. \& Jensen, J. M. (2007). Sense of Belonging in College Freshmen at the Classroom and Campus Levels. The fournal of Experimental Education, 75(3), 203-220.

Klafki, W. (2001). Dannelsesteori og didaktik: nye studier (vol. 14). Århus: Klim.

Løvlie, L. (2013). John Dewey: Danning til demokrati. I S. Straume (Red.), Danningens filosofihistorie (s. 252263). Oslo: Gyldendal Norske Forlag.

Maddox, S. J. \& Prinz, R. J. (2003). School Bonding in Children and Adolescents: Conceptualization, Assessment, and Associated Variables. Clinical Child E Family Psychology Review, 6(1), 31-49.

Maslow, A. H. (1970). Motivation and personality (2. utg.). London: Harper \& Row.

McNeely, C. \& Falci, C. (2004). School connectedness and the transition into and out of health-risk behavior among adolescents: a comparison of social belonging and teacher support. Fouranl of School Health, 74(7), 284-292. DOI: 10.1111/j.1746-1561.2004.tb08285.x.

Monahan, K. C., Oesterle, S. \& Hawkins, J. D. (2010). Predictors and consequences of school connectedness: The case for prevention. The prevention Researcher, 17(3), 3-6.

NESH. (2006). Forskningsetiske retningslinjer for samfunnsvitenskap, humaniora, juss og teologi. Oslo: De nasjonale forskningsetiske komiteer.

Newman, F. M. (1986). Priorities for the future: Towards a common agenda. Social Education, 50, $240-250$.

Nilssen, V. L. (2012). Analyse i kvalitative studier: den skrivende forskeren. Oslo: Universitetsforlaget.

Osterman, K. F. (2000). Students' Need for Belonging in the School Community. Review of Educational Research, 70(3), 323-367.

Pittman, L. D. \& Richmond, A. (2007). Academic and Psychological Functioning in Late Adoelescence: The importance of School Belonging. The fournal of Experimental Education, 75(4), 270-290.

Pittman, L. D. \& Richmond, A. (2008). University Belonging, Friendship Quality, and Psychological Adjustment During the translation to College. Fournal of Experimental Education, 76(4), 343-362. DOI: $10.3200 / \mathrm{JEXE} .76 .4 .343-362$.

Roness, D. (2011). Still motivated? The motivation for teaching during the second year in the profession. Teaching and Teacher Education, 27, 628-638.

Roness, D. \& Smith, K. (2010). Stability in motivation during teacher education. Fournal of Education for Teaching, 36(2), 169-185. DOI: 10.1080/02607471003651706. 
Skaalvik, E. M. \& Skaalvik, S. (2012). Skolen som arbeidsplass: trivsel, mestring og utfordringer. Oslo: Universitetsforlaget.

Skaalvik, E. M. \& Skaalvik, S. (2015). Job Satisfaction, Stress and Coping Strategies in the Teaching Profession - What Do Teachers Say? International Education Studies, 8(3), 181-192.

Steen-Olsen, T. (2000). Den moderne studenten: en teoretisk og empirisk analyse av mestring, trygghet og tilhørighet $i$ et motivasjons-, modernitets- og kulturperspektiv. Trondheim: Pedagogisk institutt, Fakultet for samfunnsvitenskap og teknologiledelse, NTNU.

Sundsdal, E. (2013). Richard Rorty: Med håp om en bedre fremtid. I S. Straume (Red.), Danningens filosofihistorie (s. 335-346). Oslo: Gyldendal Norske Forlag.

Thagaard, T. (2009). Systematikk og innlevelse. En innføring $i$ kvalitativ metode. Bergen: Fagbokforlaget.

Tjora, A. H. (2010). Kvalitative forskningsmetoder i praksis. Oslo: Gyldendal akademisk.

Watt, H. M. G. \& Richardson, P. W. (2007). Motivational Factors Influencing Teaching as a Career Choice: Development and Validation of the FIT-Choice Scale. The fournal of Experimental Education, 75(3), 167-202. DOI: 10.3200/JEXE.75.3.167-202.

Watt, H. M. G., Richardson, P. W., Klusmann, U., Kunter, M., Beyer, B., Trautwein, U. \& Baumert, J. (2012). Motivations for choosing teaching as a career: An international comparison using the FIT-Choice scale. Teaching and Teacher Education, 28(6), 791-805. DOI: 10.1016/j.tate.2012.03.003.

Wigfield, A. \& Eccles, J. S. (1992). The Development of Achievement Task Values: A Theroetical Analysis. Developmental Review, 12, 1-46.

Wigfield, A. \& Eccles, J. S. (2000). Expectancy-Value Theory of Achievement Motivation. Contemporary Educational Psychology, 25(1), 68-81. DOI: 10.1006/ceps.1999.1015.

Wingspread Declaration. (2004). Wingspread declaration on school connections. Fournal of School Health, 74(7), 233-234.

Zyngier, D. (2005). Advancing student engagement through changed teaching practice: What does it take to engage a student? International fournal of Learning, 12(1), 102-113. 